\title{
The protective effect of wild mustard (Sinapis arvensis L.) pollen seeds against the toxicity of a solvent (EGME) in Wistar rats
}

\author{
Leila Hamdi ${ }^{a}$ Samir Djemli ${ }^{\text {(D) }}$ | Fatma Zohra Arkoub | Rahma Boukarine ${ }^{a}$ \\ Kamel Khelili ${ }^{a}$ Cherif Abdennour ${ }^{a}$ | Abdelkrim Tahraoui
}

Animal Ecophysiology Laboratory, Department of Biology, Faculty of Sciences; Badji Mokhtar Annaba University Algeria.

Applied Neuroendocrinology Laboratory, Department of Biology, Faculty of Sciences, Badji Mokhtar Annaba University Algeria.

\begin{abstract}
Environmental pollution is the unfavorable alteration of our environment, wholly or mainly as a by-product of human actions, by the direct or indirect effects of changes in energy patterns, radiation levels, the chemical and physical constitution, and the abundance of the organisms. Thus, the environment's pollution is one of the most severe problems humanity and other forms of life face today on our planet, and this population makes severe disruption. The xenobiotic substances responsible for this pollution are numerous and diverse due to multiple human activities that can be the source. However, attention mainly focuses on fertilizers, pesticides, heavy metals, and certain petrochemicals of significant consumption, such as solvents. The purpose of this study is to highlight the reprotoxic and hepatotoxic effects of Ethylene Glycol Monoethyl Ether (EGME) on male Wistar rats. Male Wistar rats were exposed to Ethylene Glycol Monomethyl Ether alone (EGME) $(500 \mathrm{mg} / \mathrm{kg}$ ), combined with the aqueous extract of the pollen grains of Sinapis arvensis (P-EGME) (300 $\mathrm{mg} / \mathrm{kg}$ ), in addition to the control $(T)$ and positive control $(P)$ groups for a period of 4 weeks by gavage, to estimate the protective role of this plant against the intoxication of EGME. The results show that EGME can induce reprotoxic effects revealed by a reduction in testes and epididymis mass accompanied by decreased male fertility indicators (sperm concentration). The results also show that treatment with EGME caused a reduction in the red blood cell number, hemoglobin and hematocrit rate, white blood cells in the treated groups compared to the control groups. The present study revealed that treatment with Ethylene Glycol Monoethyl Ether (EGME) under the same experimental conditions could affect several biological markers, especially male fertility. Besides, the protective activity of the wild mustard (Sinapis arvensis) pollen in the face of cellular oxidative damage induced by EGME. So, it is suggested that this pollen could be used as a cell protector.
\end{abstract}

Keywords environmental pollution, ethylene glycol monoethyl ether, hematotoxicity, pollen, reprotoxicity, wild mustard

\section{Introduction}

Glycol ethers (EGs) are oxygenated solvents whose use has grown widely over the past thirty years. More than thirty glycol ethers are synthesized today by the chemical industry (INRS 2004). EGs have advantageous physicochemical properties, such as low vapor pressure and solubility in mixtures of ethanol and water, making them an excellent solvent for multiple industrial, household, and pharmaceutical applications (Boatman and Knaak 2001). They are well absorbed after dermal, inhalation or oral exposure and rapidly distributed throughout the body, where they exert a toxic influence on reproduction, development, immunological and hematological systems (Barbee et al 1984; Hardin et al 1984; Hardin et al 1984; Lamb et al 1984; Williams et al 1995; Ku et al 1995; Johanson 2000; Udden 2000; Lockley et al 2002; Starek et al 2008; Pomyerny 2014).

An endogenous defense system leads our body made up of amino acids, enzymes, antioxidant substances, among others, capable of eliminating chemical compounds (compounds of solvents). Besides, the organism's endogenous defenses are reinforced by natural antioxidants to prevent lesions' appearance due to oxidation. In this regard, the researchers wondered about the usefulness of various antioxidant molecules in supplementation in the diet, such as some minerals and trace elements (selenium, zinc, manganese, among others), vitamins $\mathrm{E}$ and $\mathrm{C}$, and polyphenols (Pastre 2005).

Pollen is a natural product collected by bees from selected flower species, mixed with nectar and bee secretions (Le Blanc et al 2009; Nakajima et al 2009). It has been used as a health food supplement, even used as a medicine for many years (Linskens and Jorde 1997) due to its excellent nutritive properties, including sugars, proteins, fats, vitamins, carbohydrates, and phenolic compounds (Campos et al 2003). Phenolic compounds are one of the most important ingredients linked to the antioxidant activity of pollen. Usually, it contains vanillic acid, protocatechuic acid, gallic acid, p-coumaric acid, hesperidin, rutin, kaempferol, 
apigenin, luteolin, quercetin, and isorhamnetin (Bonvehí et al 2001; Chu et al 2007).

This composition tends to be species-specific and linked to the therapeutic properties (antibiotic, antineoplastic, anti-diarrheal, and antioxidant) of pollen (Campos et al 1997; Almaraz-Abarca et al 2004; Mărghitaş et al 2009).

Our work aims to determine the effects of EGME administered by gavage on male reproduction (concentration and mobility) and some hematological parameters in Wistar rats. On the other hand, we have tried to determine the phytochemicals of aqueous extract of pollen grains of wild mustard (Sinapis arvensis L.) and their protective effect against the toxicity induced by this solvent.

\section{Materials and Methods}

\subsection{Biological material}

In this study, we used 32 male rats from the Pasteur Institute in Algiers. These rats were subjected to an adaptation period of about one month to the biology department animal facility (room temperature and natural photoperiod). The rats are kept in plastic cages. The cages were cleaned, and the litter was changed every three days until the end of the experiment. The animals had ad libitum access to water with food containing all the necessary elements (maize, soybeans, minerals, and vitamins) from Oued Fragha-Guelma. Each group was assigned the same amount.

\subsection{Chemical material}

A solvent from the family of oxygenated solvents was used: ethylene glycol monoethyl (\%), obtained from Biochem chemopharma. EGME was dissolved in water and then administered orally at a dose of $500 \mathrm{mg} / \mathrm{kg} \mathrm{BW}$.

\subsection{Vegetal material}

The plant, which was the object of our study, is known under the name Field mustard (Sinapis arvensis L.), from which we used the pollen grains. Our samples' collection was carried out during April, at the El Chafia region level (Wilaya of ELTarf).

\subsubsection{Preparation of the extract}

The aqueous pollen grain extract of Wild Mustard (Sinapis arvensis L.) was made in the form of a suspension. Daily, the pollen grains were ground with a commercial grinder, then mixed with distilled water and administered orally at $300 \mathrm{mg} / \mathrm{kg} \mathrm{BW}$.

\subsection{Experimental protocol}

The thirty-two male rats were divided to have an average weight per equal group, into six experimental groups of eight rats each $(n=8)$ and received the following treatments:

-The control group $(T)$ : received tap water as drinking water.
-The positive control group $(\mathrm{P})$ : received orally $1 \mathrm{ml}$ of an aqueous suspension of wild mustard pollen (Sinapis arvensis L.) grain at a rate of $300 \mathrm{mg} / \mathrm{kg} \mathrm{BW}$.

-The group (EGME): rats treated orally with $1 \mathrm{ml}$ of ethylene glycol monoethyl at a rate of $500 \mathrm{mg} / \mathrm{kg} \mathrm{BW}$.

-The group (P-EGME): rats treated with a mixture of the aqueous suspension of pollen grains of wild mustard (Sinapis arvensis L.) (300 mg/kg BW) with EGME (500 mg/kg BW).

The rats are sacrificed by cervical decapitation without anesthesia to avoid keeping them in a state of stress.

\subsection{Sample collection}

\subsubsection{Blood sample}

The blood was immediately collected in tubes containing an anticoagulant (EDTA) to measure the hematological parameters.

\subsubsection{Dissection}

After the dissection, the testes and epididymis were removed and stripped of their fatty tissue, then weighed using a precision balance (Kern PRS 320-3).

\subsection{Study of hematological parameters}

The measurement of the blood count formula was carried out using an automatic hematology machine (Brand: ABACUS 4). The EDTA tube containing the blood is placed in the machine, and the SNSF measurement begins. After 2 minutes, the results appear on the screen, and then we print them out. The hematological parameters measured were red blood cell (GR), white blood cell (GB), hemoglobin ( $H b)$, hematocrit (HT).

\subsection{Study of the biology of spermatozoa}

After dissection, the sperm is taken from a small opening in the epididymis's tail to study: the concentration and mobility of the sperm. $1 \mu \mathrm{l}$ of semen is diluted in $50 \mu \mathrm{l}$ of physiological $\mathrm{Na} \mathrm{Cl} 0.9 \%$ solution.

\subsubsection{The concentration and mobility of sperm}

The latter is measured using the sperm class analyzer (SCA) by putting a drop of the sperm into the Goldcyto blade (made up of several counting chamber formats). This preparation was examined under a microscope-integrated into the microcomputer at a final magnification $x 4$, programmed to calculate the sperm concentration and motility.

\subsection{Statistical study}

Data were expressed as mean $\pm S E M$. Statistical analysis and graphs were performed with Prism7. The oneway analysis of variance (ANOVA) test was used to compare more than two groups. The criterion of statistical significance was set at $P<0.05$.

\section{Results}




\subsection{Absolute testis weight}

Rats intoxicated with EGME show a very significant decrease $(P<0.001)$ in the absolute testicular weight compared to the control and positive control groups. In contrast, oral administration of the aqueous extract of pollen grains $(P)$ to EGME poisoned animals significant $(P<0.05)$ increased weight and testes compared to animals from the EGME (Figure 1).

\subsection{Sperm concentration and motility}

The sperm concentration was highly significantly $(P<$ 0.01 ) decreased in the rats in the (EGME) group compared to controls and positive controls. This concentration increased

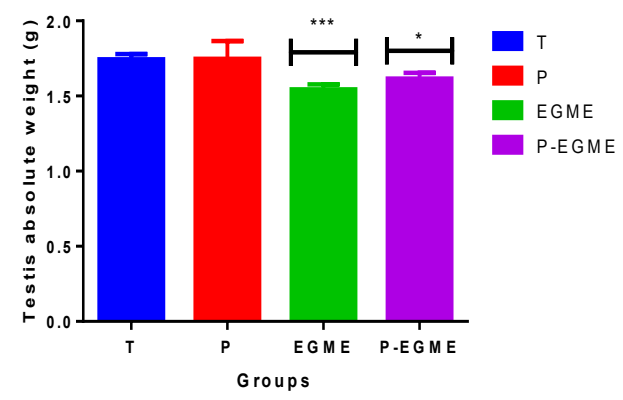

Figure 1 Changes in the absolute weight of testis $(\mathrm{g})$ in the groups of rats: T, $\mathrm{P}, \mathrm{EGME}, \mathrm{P}-\mathrm{EGME}(\mathrm{n}=8) .{ }^{*} P<0.05 ;{ }^{* *} P<0.01{ }^{* * *} P<$ 0.001 .

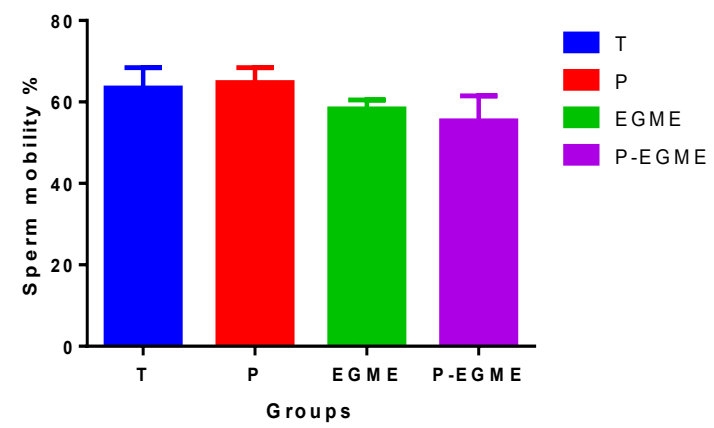

Figure 3 Variation in sperm motility (\%) in the groups of rats: $T, P$, EGME, and P-EGME $(\mathrm{n}=8) . * P<0.05 ; * * P<0.01$; $* * * 0.001$.

\subsubsection{Hemoglobin level}

We find a significant decrease $(P<0.05)$ in hemoglobin level in the animals of the (EGME) group compared to the intake in the $(T)(P)$ groups. On the other hand, the combination of aqueous extract of pollen grains and EGME increased in a highly significant way $(P<0.01)$ this hemoglobin level compared to those of the group (EGME) (Figure 5).

\subsubsection{Hematocrit level}

Our results show a significant decrease $(P<0.05)$ in the hematocrit level of the group's animals (EGME) compared in a highly significant way $(P<0.01)$ in the animals of the group (P-EGME) compared to those of the group (EGME) (Figure 2). No significant change $(P<0.05)$ was recorded in sperm motility in our study's different groups (Figure 3 ).

\subsection{Hematological study}

\subsubsection{Number of red blood cells}

Treatment of rats with EGME induced a significant decrease $(P<0.05)$ in the number of red blood cells compared to control and positive control rats, as well as a non-significant reduction $(P>0.05)$ in rats treated with the combination aqueous extract of pollen grains and EGME comparing to rats treated with EGME alone (Figure 4).

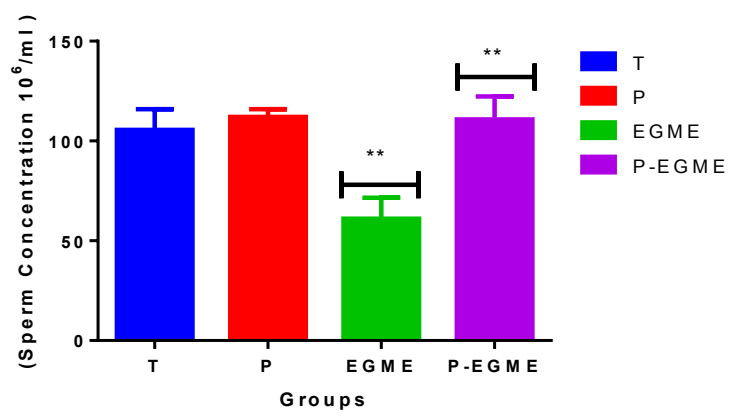

Figure 2 Variation in the concentration of spermatozoa $(106 / \mathrm{ml})$ in the groups of rats: T, $\mathrm{P}, \mathrm{EGME}, \mathrm{P}-\mathrm{EGME}(\mathrm{n}=8) .{ }^{*} P<0.05 ;{ }^{* *} P<0.01 ; * * *$ $P<0.001$.

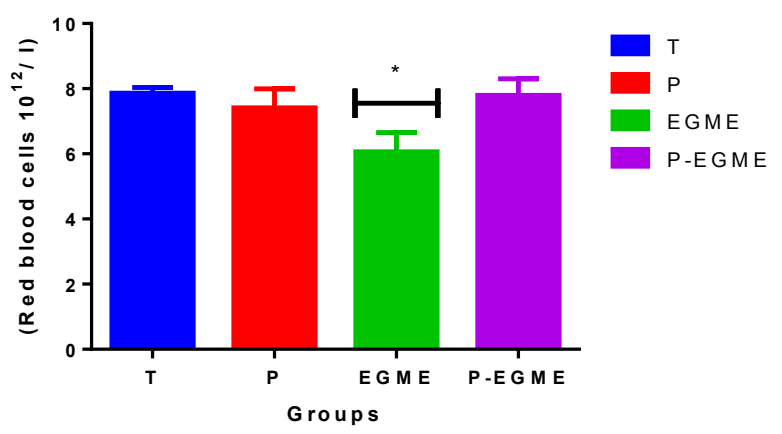

Figure 4 Variation in the number of red blood cells $\left(10^{12} / \mathrm{l}\right)$ in the groups of rats: T, P, EGME, and P-EGME $(\mathrm{n}=8){ }^{*} P<0.05$; ${ }^{* *} P<0.01$; *** $P<$ 0.001 .

to controls and positive controls. This drop in the hematocrit level increased significantly $(P<0.05)$ in animals in the $(P$ EGME) group compared to those in the (EGME) group (Figure 6).

\subsubsection{Number of white blood cells}

From the results obtained, there was a significant increase $(P<0.05)$ in the number of white blood cells in the animals treated with EGME compared to controls and positive controls. This considerable increase improved significantly $(P<0.05)$ in animals poisoned with EGME and treated with the aqueous extract of the pollen grains compared to animals treated with EGME alone (Figure 7). 


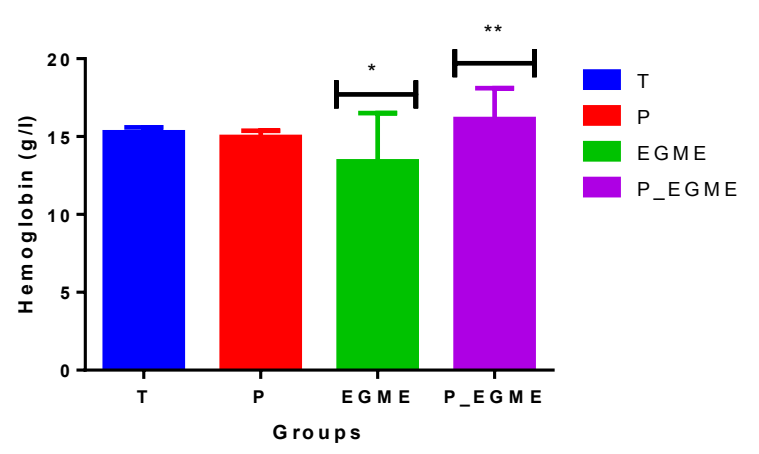

Figure 5 Change in hemoglobin level $(\mathrm{g} / \mathrm{l})$ in the groups of rats: $\mathrm{T}$, P, EGME, and P-EGME $(\mathrm{n}=8) .{ }^{*} P<0.05 ;{ }^{* *} P<0.01 ; * * *<$ 0.001 .

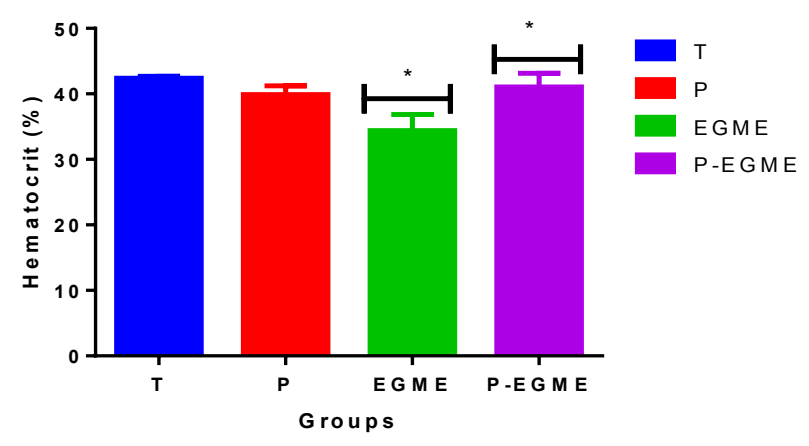

Figure 6 Variation in the hematocrit level (\%) in the groups of rats: T, P, EGME, and P-EGME $(\mathrm{n}=8) . * P<0.05$; ** $P<0.01$; *** $P<0.001$.

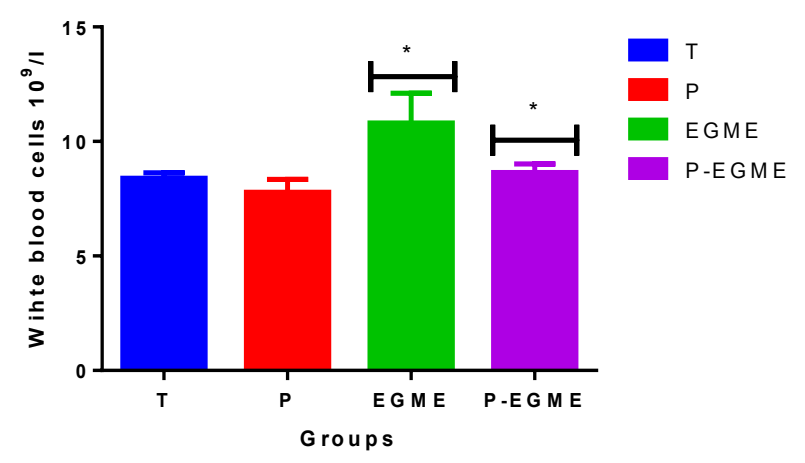

Figure 7 Variation in the number of white blood cells (109 / I) in the groups of rats: T, $P, E G M E$, and P-EGME $(n=8) . * P<0.05 ;{ }^{* *}$ $P<0.01 ; * * * P<0.001$

\section{Discussion}

Since ancient times humankind has used various plants in their habitats to treat and cure all kinds of diseases. These plants represent a very vast reservoir rich in potential compounds attributed to "secondary metabolites", which have the advantage of having a great diversity of chemical structures and possessing an enormous range of biological activities (Laouar 2018).

In recent years, attention has been focused on one of the medicinal plants' biological activities, the antioxidant activity. This attention is due to the role on plays in the prevention of chronic diseases by combating the oxidative stress induced by several factors such as pollution, smoking, aging, and psychological stress but especially intoxication by xenobiotics (Boelsterli 2007; Lodovici and Bigagli 2011; Verschuere et al 2012; Aschbacher et al 2013; Meddour et al 2013; Siriwardena 2014).

Glycol ethers represent a diverse series of dexenobiotics with properties that make them widely suitable for various solvent applications. Their hydrophilic and lipophilic properties have wide industry applications (Johanson 2000; Bagchi and Waxman 2008). On the other hand, these compounds or their metabolites can induce many pathological cases, particularly hematopoietic, reproductive and developmental toxicities (Bagchi and Waxman 2008).

In this study, we investigated the toxic effect of EGME on reproductive and hematological parameters. Besides, we investigated the protective effect of aqueous extract of wild mustard (Sinapis arvensis) against EGME toxicity.

Reproduction is an important biological function that ensures continuity and biodiversity. It is a fundamental process that allows living organisms to conserve their offspring and evolve by passing on genes (Fujii et al 2003). Epidemiological data have shown that the quality of human sperm has declined over the past 60 years, while the incidence of abnormalities of the male genital tract and infertility has increased (Auger et al 1995; Miguel et al 2006; Phillips and Tanphaichitr 2008).

The decline in sperm quality observed in men developed over a short period, suggesting that it could result from environmental factors (Phillips \& Tanphaichitr, 2008). Among the factors that affect male fertility and normal sperm parameters, chemical compounds play an essential role (Tas et al 1996). Many chemicals used for other conditions can negatively affect sperm motility and viability (Hargreaves et al 1998).

Our study results show a considerable decrease in the absolute weights of the testes and epididymis of rats treated with EGME compared to the control and positive control groups. A similar study showed the same observations in rats treated with $200 \mathrm{mg} / \mathrm{kg}$ BW EGME over 40 days (AdeyemoSalami and Farombi 2018). Exposure to glycol ethers can cause deleterious effects on the structure and function of the sexual organs (Holloway et al 1990).

Microscopic examination of a histologic study of the testes and epididymis revealed pathologic lesions associated with treatment at $400 \mathrm{mg} / \mathrm{kg}$ BW EGME. The testes treated with EGME showed severe congestion and bleeding in the interstitium seminiferous tubules, severe erosion of the germinal epithelium of almost all seminiferous tubules, severe necrosis of germ cells with a significantly reduced Sertoli cell population (Adedara and Farombi 2010).

EGME has also been shown to cause gonadotoxicity by inducing oxidative stress in testes and epididymis, as demonstrated by the effect on membrane components by lipid peroxidation, which is an indication of oxidative 
degradation of lipids by free radicals (Adeyemo-Salami and Farombi 2018).

The evaluation of the effects of EGME on the quality and quantity of sperm showed a significant decrease in some biological parameters of the sperm (concentration and rate) in rats treated with EGME alone compared to controls.

The observed decrease in sperm concentration may indicate that EGME affects the early stages of spermatogenesis, which is well supported by the observed reduction in daily sperm production (Wang et al 2004; Welsch 2005).

The first wave of spermatogenesis in rats is triggered when the gonocytes first differentiate into spermatogonia three days after birth; these first become spermatocytes at around day 9 , form haploid spermatids by day 18 form the first spermatozoa at day 43 (de Rooji 1998). Each phase of spermatogenesis has different susceptibilities to various toxins. Often, exposure to a specific toxicant targets a spermatogenesis phase, depending on the toxicant mode of action (Adedara and Farombi 2010).

Ethylene glycol mono-ethyl ether has been reported to negatively affect early and late pachytenes and dividing spermatocytes (Watanable et al 2000). It has also been reported to reduce testicular testosterone, which regulates both Sertoli and germ cells during spermatogenesis (Reader et al 1991). As another significant testicular toxicity mechanism, the effect of oxidative stress on testicular toxicity must be taken into account (Yamamoto et al 2007).

An earlier study marked reactive oxygen species (ROS) involvement in infertility due to impaired sperm function (Aitken et al 1987; Agarwal et al 2014). Adeyemo-Salami and Farombi (2018) reported that oral administration of EGME at $400 \mathrm{mg} / \mathrm{kg} \mathrm{BW}$ in adult male rats for 15 days causes a disturbance in enzymatic and non-enzymatic antioxidants, with an increase in the rate of lipid peroxidation; this could alter sperm morphology by affecting components of the sperm membrane, such as phosphocholine, phosphatidylcholine, and lipids (Yamamoto et al 2007).

EGME's effect on sperm motility may be due to their action at the middle part and flagellum. These two areas are the parts that ensure the movement and speed of the sperm (fertility indicators). Foster et al (1983) showed that the first visible lesion in pachytene spermatocytes is in the mitochondria and that damage to spermatids with elongated nuclei results in reduced sperm movement; this may explain the decrease in lactate production in the Sertoli cell (Mebus et al 1989). The latter is considered the key enzyme to provide the energy necessary for sperm speed and mobility by converting pyruvate to lactate attached by $\mathrm{NADH}$ oxidation to NAD and catalysis by lactate dehydrogenase (LDH) (Miki et al 2004; Miki 2007).

The hematologic system can be considered a conductor for substances that enter the body and as an organ that can be affected by exposure to potentially harmful agents. Blood samples can serve as biological control of exposure and provide the means to assess a toxicant's effects on the hematopoietic system and other organs. Agents in the environment can interfere with the hematopoietic system in several ways: by inhibiting hemoglobin synthesis, as well as cell production or function, and by accelerating the destruction of red blood cells (Dufresne 2000).

This study shows the effects of EGME on the blood compartment. Based on the results obtained, a decrease in the erythrocyte count, hematocrit, hemoglobin level, and white blood cells was observed in rats exposed only to EGME. Therefore, these observations are consistent with Bendjedou and Khelili (2014), who found that treating male rabbits at 300 ppm EGME for four weeks corroborates our conclusions.

Based on these observations, the authors suggested that the decline in blood elements could be attributable to hemolytic anemia (cell lysis) caused by the toxin's ability to act directly on erythrocytes causing massive extravascular hemolysis or d " induce oxidative stress (Hashish and Elgaml 2016; Lalruatfela et al 2014; Demur et al 2013).

Although devoid of mitochondria, red blood cells or erythrocytes are susceptible to free radicals (Demur et al 2013; Brun et al 1998). Oxidative stress can alter the erythrocyte membrane by attacking membrane lipids, thereby making cell membranes more fragile and causing red blood cell lysis (Hashish and Elgaml 2016; Lalruatfela et al 2014).

EGME may also impact the immune system, resulting in decreased thymus weight, thymic atrophy, and a reduced number of spleen cells (Exon et al 1991).

In this study, therapeutic intervention in EGME poisoned rats with Sinapis arvensis pollen grain extract at a $300 \mathrm{mg} / \mathrm{kg}$ BW dose effectively attenuated the deleterious effects of EGME on reproduction, restoring the weight of reproductive organs with concomitant improvements in the concentration and mobility of sperm. Besides, the coadministration of aqueous extract of wild mustard pollen grains was found to be effective in protecting hematological parameters against the detrimental effect of EGME, thereby increasing cellular defense processes against -vis the cytotoxic effects of free radicals.

The observed therapeutic potency of wild mustard (Sinapis arvensis) pollen grains could be due to several contributing factors, including phenolic compounds, flavonoids, and carotenoids (Abdeldjalil 2014). These compounds have been shown to reduce lipid peroxidation and LDL oxidation levels by removing free radicals from hydroxyl and superoxide anions (Tiwari 1999; Jovanovic and Simic 2000). Besides, stimulate transcription of SOD and catalase genes ( Toyokuni et al 2003; Ranaivo et al 2004), thus increasing antioxidant activities and reducing oxidative damage induced by free radicals in human cells.

\section{Conclusions}

Administration of EGME $500 \mathrm{mg} / \mathrm{kg} \mathrm{BW}$ to rats for 30 days caused a metabolic disturbance as evidenced by the onset of impairment of reproductive and hematological parameters. This disturbance is associated with structural alteration of the testes, epididymis, and bone marrow. Besides, it is responsible for the appearance of significant 
changes induced by oxidative stress that disrupt the enzymatic detoxification systems and the body's defensive capacities.

Through our study, our results also show that the administration of the aqueous extract of the grains of wild mustard pollen (Sinapis arvensis) $(300 \mathrm{mg} / \mathrm{kg} \mathrm{BW}$ ) to animals treated with EGME leads to the improvement of most of the parameters studied.

The results of this study seem to suggest that wild mustard (Sinapis arvensis) provided a protective effect against reprotoxicity and haemato-toxicity induced by EGME, and this thanks to its composition in polyphenols and flavonoids responsible for the antioxidant potential of this plant.

\section{Conflict of Interest}

The authors declare that there are no conflict of interest with this work.

\section{Funding}

This research did not receive any financial support.

\section{References}

Aasmoe L, Winberg JO, Aarbakke J (1998) The Role of Liver Alcohol Dehydrogenase Isoenzymes in the Oxidation of Glycolethers in Male and Female Rats. Toxicology and Applied Pharmacology 150:86-90.

Abdljalil A (2014) Quelques aspects germinatifs, rhizogénique et écologiques chez Sinapis arvensis. $L$ dans la région de Tlemcen. Thèse présentée en vue de l'obtention de diplôme de master 2 en département d'écologie et environnement, université de Tlemcen.

Adedara IA, Farombi EO (2010) Induction of oxidative damage in the testes and spermatozoa and hematotoxicity in rats exposed to multiple doses of ethylene glycol monoethyl ether. Human \& Experimental Toxicology 29:801812.

Adeyemo-Salami OA, Farombi EO (2018) Sub-Acute Toxicity Study of Ethylene Glycol Monomethyl Ether on the Antioxidant Defense System of the Testes and Epididymes of Wistar Rats. Niger J Physiol Sci 33:195-200.

Agarwal A, Virk G, Ong C, du Plessis SS (2014) Effect of Oxidative Stress on Male Reproduction. The World Journal of Men's Health 32:1.

Aitken RJ, Clarkson JS (1987) Cellular basis of defective spermatozoa function and its association with the genesis of reactive of reactive oxygen species by human spermatozoaatozoa. J Reprod and Fertl 81:459-469.

AlfiahHayati, Amilia Mahmuda IB, Rai Pidada (2010) 2-Methoxyethanol exposure affects protein profile of testicular sperm membrane in mice (musmusculus). Folia Medicalndonesiana 46:253-256.

Almaraz-Abarca N, Campos MG, A' vila-Reyes JA, NaranjoJime'nez N, Herrera-Corral J, Gonza'lez-Valdez LS (2004) Variability of antioxidant activity among honeybee-collected pollen of different botanical origin. Interciencia 29:574-578.

American Conference of Governmental Industrial Hygienists (ACGIH) (2007) Threshold Limit Values for Chemicals Substances and Physical Agents. Cincinnati OIH.

Aschbacher K1, O'Donovan A, Wolkowitz OM, Dhabhar FS, Su Y, Epel E (2013) Good stress, bad stress and oxidative stress : insights from anticipatory cortisol reactivity. Psychoneuroendocrinology 38:1698-708.

Auger JM, Kunstmann F Czyglik, P Jouannet (1995) Decline in semen quality among fertile men in Paris during the past 20 years. New England Journal of Medicine 332:281-285.
Bagchi G, Waxman DJ (2008) Toxicity of ethylene glycol monomethyl ether: impact on testicular gene expression. International Journal of Andrology 31:269-274.

Barbee SJ, Terrill JB, DeSousa DJ, Conaway CC (1984) Subchronic inhalation toxicology of ethylene glycol monoethyl ether in the rat and rabbit. Environ Health Perspect 57:157-163.

Bartnik FG, Reddy AK, Klecak G, Zimmermann V, Hostynek JJ, Kunstler K (1987) Percutaneous absorption, metabolism, and hemolytic activity of $n$ butoxyethanol. Fundam Appl Toxicol 8:59-70.

Bendimerad SD, Taleb Bendiab AK, Benabadji N, Fernandez X, Vallette L, Lizzani-Cuvellier, Benabadji N (2005) Composition and Antibacterial Activity of Pseudocytisusintegrifolius (Salisb) essentiel, Oil from Algeria. Jour Agric Food Chem 53:2947-2952

Bendjeddou M, Khelili K (2014) The toxic effects of the ethylene glycol monomethyl ether (EGME) in male rabbit. Annals of Biological Research 5:815.

Berndtson WE, Foote RH (1997) Disruption of spermatogenesis in rabbits consuming ethylene glycol monomethyl ether. Reprod Toxicol 11:29-36.

Boatman RJ, Knaak JB (2001) Ethers of Ethylene Glycol and Derivatives. In: Bingham E, Cohressen B, Powell CH (eds) Patty's toxicology, 5th edn. Wiley, New York, pp 73-270.

Boelsterli UA (2007) Mechanistic toxicology: The molecular basis of how chemicals disrupt biological targets. CRC Press, pp 117.

Bonvehí SJ, Torrentó SM, Lorente CE (2001) Evaluation of Polyphenolic and Flavonoid Compounds in Honeybee-Collected Pollen Produced in Spain. Journal of Agricultural and Food Chemistry 49:4.

Browning E (1965) Toxicity and metabolism of organic solvents. Elsevier, Amsterdam, Netherlands, pp 632-634.

Brun J, Khaled S, Raynaud E, Bouix D, Micallef J, Orsetti A (1998) The triphasic effects of exercise on blood rheology: Which relevance to physiology and pathophysiology. Clinical Hemorheology and Microcirculation 19:89-104.

Bucfhanan G (1973) Crop loss assessment methods. F.A.O .Manuel fiche $n^{\circ}$ 97.

Butterworth M, Creasy D, Timbrell JA (1995) The detection of subchronic testicular damage using urinary creatine: studies with 2-methoxyethanol. Arch Toxicol 69:209-211.

Campos MG, Webby RF, Markham KR, Mitchell KA, Da Cunha AP (2003) Ageinduced diminution of free radical scavenging capacity in bee pollens and the contribution of constituent flavonoids. Journal of Agricultural and Food Chemistry 51:742-745.

Campos MG, Markham K,Cunha A (1997) Bee-pollen: composition, properties and applications. In Mizrahi, A (Ed) Bee Products. Plenum Publishing Company; London, UK pp 93-100.

Carpenter CP, Smyth HF Jr (1946) Chemical burns of the rabbit cornea. Am J Ophthalmol 29:1363-1372.

Chu QC, Tian XH, Jiang LM, Ye JN (2007) Application of capillary electrophoresis to study phenolic profiles of honeybee-collected pollen. J Agric Food Chem 55:8864-8869.

Cragg GM, Newman DJ (2001) Pharmaceutical Biology pp 8-17.

De Ketttenis P (2005) The historic and current use of glycol ethers: a picture of change. Toxicology Letters 156:5-11.

De Rooji (1998) Stem cells in the testis. Int J Exp Path 79:67-80.

Demur C, Métais B, Canlet C, Tremblay-Franco M, Gautier R, Blas-Y-Estrada F, Sommer C, Gamet-Payrastre L (2013) Dietary exposure to a low dose of pesticides alone or as a mixture: The biological metabolic fingerprint and impact on hematopoiesis. Toxicology 308:74-87.

Denkhaus W, Steldern D, Botzenhardt U and Konietzko H (1986) Lymphocyte subpopulations in solvent-exposed workers, Int Arch Occup Environ Health 57:109-115. 
Derosa G, Cicero AF, Murdolo G, Ciccarelli L, Fogari R (2004) Comparison of metabolic effects of orlistat and sibutramine treatment in Type 2 diabetic obese patients, Diabetes Nutr Metab 17:222-229.

Devillers J, Chessel D (1995) Can the enucleated rabbit eye test be a suitable alternative for the in vivo eye test? A chemometrical response. Toxicol Mode 1:21-34.

DMER (Don Mackay Environmental Research) (1996) Pathways analysis using fugacity modelling of 2-methoxyethanol for the second Priority Substances List. Rapport préparé pour la Division de l'évaluation des produits chimiques, Direction de l'évaluation des produits chimiques commerciaux, Environnement Canada, par DMER, Peterborough (Ont.), et AEL, Don Mills (Ont.).

Donley DE (1936) Toxic encephalopathy and volatil solvents in industry: report of case. J Ind Hyg Toxicol 18:571-577.

Dufresne C (2000) Encyclopédie de sécurité et de santé au travail, Organisation internationale du travail. pp 11-18.

European Centre for Ecotoxicology and Toxicology of Chemicals (ECETOC) (2005) The Toxicology of Glycol Ethers and its Relevance to Man. Brussels, Belgium, Fourth Edition. Volume II - Substance Profiles. Pp 496.

European Centre for Ecotoxicology and Toxicology of Chemicals (ECETOC) (1995) The toxicology of glycol ethers and its relevance to man, Bruxelles (Belgique), pp 350.

European Center for Ecotoxicology and Toxicology of Chemicals (ECETOC WORKING GROUP) (1995) Technical Report. The toxicology of glycol ethers and its relevance to man. Eur Center Ecotoxicol Toxicol Chemicals 64:1-348.

European Center for Ecotoxicology and Toxicology of Chemicals (ECETOC) (1994). The toxicology of glycol ethers and its relevance to man. Technical report $\mathrm{N}^{\circ} 64$

Etiemble J (2003) Les éthers de glycol :Une toxicité variable selon les composés. Chimie et santé publique, pp 145-149.

Exon JH, Mather GG, Bussiere JL, Olson DP, Talcott PA (1991) Effects of subchronic exposure of rats to 2-methoxyethanol or 2- butoxyethanol: thymic atrophy and immunotoxicity. Fundam Appl Toxicol 16:830-840.

Foote RH, Farrel PB, Schlafer DH, McArdle MM, Trouern-Trend V, Simkin ME, Brockett CC, Giles JR, Li J (1995) Ethylene glycol monomethyl ether effects on health and reproduction in male rabbits. Reprod Toxicol 9:527-539.

Foster PMD, Creasy DM, Foster JR, Thomas LV, Cook MW, Gangolli SD (1983) Testicular toxicity of ethylene glycol monomethyl and monoethyl ethers in the rat. Toxicol Appl Pharmacol 69:385-399.

Fujii J, luchi Y, Matsuki S, Ishii T (2003) Cooperative function of antioxidant and redox systems against oxidative stress in male reproductive tissue. Asian Journal of Andrology 5(3):231-42.

Gargi Bagchi, David J Waxman (2008) Toxicity of ethylene glycol monomethyl ether: impact on testicular gene expression. International Journal of Andrology 31:269-274.

Gomez-Campo C (1999) Biologyof Brassicacoeno species Elsevier Amsterdam.

Greenburg L, Mayers MR, Goldwater LJ, Burke WJ, Moskowitz S (1938) Health hazards in the manufacture of "fused collars." I. Exposure to ethylene glycol monomethyl ether. J Ind Hyg Toxicol 20:134-147.

Groeseneken D, Veulemans H, Masschelein R, Van Vlem E (1989) Experimental human exposure to ethylene glycol monomethyl ether. Int Arch Occup Environ Health 61:243-247.

Hall JC, Sytsma KJ, Iltis HH (2002) Phylogeny of Capparaceae and Brassicaceae based on chloroplast sequence data. Ann J Bot 89:1826-1842.

Hardin BD, Goad PT, Burg JR (1984) Developmental toxicity of four glycol ethers applied cutaneously to rats. Environ Health Perspect 57:69-74.

Hargreaves CA, Rogers S, Hills F, Rahman F, Howell RJ, Homa ST (1998) Effects of co-trimoxazole, erythromycin, amoxycillin, tetracycline and chloroquine on sperm function in vitro. Hum Reprod 13:1878-1886.

Hashish EA, Elgaml SA (2016) Role of nicotinic acid in mitigating methomyl induced acute toxicity in albino rats. J Clin Exp Pathol 6:268.
Holloway AJ, Moore HD and Foster PM (1990) The use of rat in vitro fertilization to detect reductions in the fertility of spermatozoa from males exposed to ethylene glycol monomethyl ether. Reprod Toxicol 4:21-27.

Hong HL, Canipe J, Jameson CW, Boorman GA (1988) Comparative effects of ethylene glycol and ethylene glycol monomethyl ether exposure on hematopoiesis and histopathology in B6C3F1 mice. J Environ PatholToxicol Oncol 8:27-38.

Howard JA, Joly HA and Mile B (1990) Reaction of ground-state aluminium atoms with diethyl ether. Electron spin resonance evidence for insertion into the $\mathrm{CH}$ and $\mathrm{CC}$ bonds. Journal of the Chemical Society, Faraday Transactions $86: 219-220$

Howard PH (1990) Handbook of environmental fate and exposure data for organic chemicals, vol. II, Solvents, Lewis Publishers Inc., Chelsea (Mich.).

Institut national de recherche et de sécurité (INRS) (2014) 2Méthoxyéthanol. Fiche toxicologique $n^{\circ} 103$.

Institut National de Recherche et de Sécurité(INRS) (2010) 2 Méthoxyéthanol (EGME). Fiche DEMETER (Documents pour l'évaluation médicale des produits toxiques vis-à-vis de la reproduction). $\mathrm{N}^{\circ} \mathrm{DEM} 008, \mathrm{FT}$ INRS $n^{\circ} 103$.

Institut national de recherche et de sécurité (INRS) (2004) Les éthers de glycol. Fic. Sol. Ed., 4222 pp 1-6.

Institut national de recherche et de sécurité (INRS) (1999) Fiche toxicologique. 103 : 2-Méthoxyéthanol.

Institut National de la Santé et de la Recherche Médicale(INSERM) (1999) Ethers de glycol: quels risques pour la santé. Paris, France: Éditions Inserm.

International Programme on Chemical Safety (IPCS) (1990) Environmental Health Criteria 115. 2-Methoxyethanol, 2-ethoxyethanol, and their acetates, International Programme on Chemical Safety, World Health Organization, Geneva.

Iyyanki V, Muralikrishna, Valli Manickam (2017) Environmental management science and engineering for industry all book details. Butterworth-Heinemann; $1^{\text {a }}$ edn, pp 664.

Jacobs G, Martens M, Mosselmans G (1987) Proposal of limit concentrations for skin irritation within the context of a new EEC directive on the classification and labelling of preparations. Regul Toxicol Pharmacol 7:370378.

Jacobs GA, Castellazzi A, Dierickx PJ. (1989). Evaluation of a non-invasive human and an in vitro cytotoxicity method as alternatives to the skin irritation test on rabbits. Contact Dermatitis 21:239-244.

Johanson G (2000) Toxicity review of ethylene glycol monomethyl ether and its acetate ester. Crit Rev Toxicol 30:307-345.

Johanson G (1996) An overview of glycol ethers metabolism and toxicokinetics. Occup Hyg 2:5-24

Jovanovic SV and Simic MG (2000) Antioxidants in nutrition. Ann NY Acad Sci 899:326-334

Kawamoto T, Matsuno K, Kayama F, Arashidani K, Yoshikawa M, Kodama Y (1992) The effect of ethylene glycol monomethyl ether and diethylene glycol monomethyl ether on hepatic gamma-glutamyltranspeptidase. Toxicology 76:49-57.

Ku WW, Wine RN, Chae BY, Ghanayem BI, Chapin RE (1995) Spermatocyte toxicity of 2-methoxyethanol (ME) in rats and guinea pigs: evidence for the induction of apoptosis. Toxicol Appl Pharmacol 134:100-110.

Lalruatfela PL, Saminathan M, Ingole RS, Dhama K, Joshi MV (2014) Toxicopathology of paraquat herbicide in female wistar rats. Asian Journal of Animal and Veterinary Advances 9:523-542.

Lamb JC, Gulati DK, Russell VS (1984) Reproductive toxicity of ethylene glycol monoethyl ether tested by continuous breeding of CD-1 mice. Environ Health Perspect 57:85-90.

Lambinon J, Delvosalle L, Duvigneaud J (2004) Nouvelle flore de la Belgique, du Grand-Duché de Luxembourg, du Nord de la France et des Régions voisines. Jardin Botanique National de Belgique. Meise. 
Laouar A (2018) Exploration de l'impact des extraits naturels d'origine végétale "Juniperus phoenicea " sur la toxicité induite par le tétrachlorure de carbone chez le rat. Thèse présentée en vue de l'obtention du diplôme de doctorat en biochimie, Université Badji-Mokhtar-Annaba.

Lazewska M, Tabarowski Z, and Dabrowski Z (1993) Effect of small doses of ethylene glycol monomethyl ether on the acetylcholinesterase and deltaaminolevulinic acid dehydratase activity in erythrocytes, blood and bone marrow of rats, Toxicol Ind Health 9:617-622.

LeBlanc BW, Davis OK, Boue S, De Lucca A, Deeby T (2009). Antioxidant activity of Sonoran Desert bee pollen. Food Chemistry 115:1299-1305.

Linskens HF, Jorde W (1997) Pollen as food and medicine-A review. Economic Botany 51:78-87.

Lockley DJ, Howes D, Williams FM (2002) Percutaneous penetration and metabolism of 2-ethoxyethanol. Toxicol Appl Pharmacol 180:74-82.

Lodovici M and Bigagli E (2011) Oxidative Stress and Air Pollution Exposure. Journal of Toxicology 12:1-9.

Mărghitaş LA, Stanciu OG, Dezmirean DS, Bobis O, Popescu O, Bogdanov S (2009) In vitro antioxidant capacity of honeybee-collected pollen of selected floral origin harvested from Romania. Food Chem 115:878-883.

Mebus CA, Welsch F (1989) The possible role of one-carbon moieties in 2methoxyethanol and 2-methoxyacetic acid-induced developmental toxicity. Toxicol Appl Pharmacol 99:98-109.

Meddour A, Yahia M, Benkiki N, Ayachi A (2013) Etude de l'activité Antioxydante et antibactérienne des extraits d'un ensemble des parties de la fleur du Capparis spinosa L. Lebanese Science Journal 14:49-60.

Miguel BR, Alicia C, Eduardo (2006) Effect of two insecticide and two herbicides on the porcine sperm motility patterns using computer-assisted semen analysis (CASA) in vitro. Reproductive Toxicology 22:508-512.

Miki K (2007) Energy metabolism and sperm function. Society of Reproduction and Fertility supplement 65:309-325.

Miki K, Qu W, Goulding EH, Willis WD, Bunch DO, Strader LF, Perreault SD, Eddy, EM, O'Brien DA. (2004) Glyceraldehyde 3-phosphate dehydrogenase$\mathrm{S}$, a sperm-specific glycolytic enzyme, is required for sperm motility and male fertility. Proceedings of the National Academy of Sciences 101:16501-16506.

Miller RR, Ayres JA, Calhoun LL, Young JT, McKenna MJ (1981) Comparative short-term inhalation toxicity of ethylene glycol monomethyl ether and propylene glycol monomethyl ether in rats and mice. Toxicol Appl Pharmacol 61:368-377.

Miller RR (1983) Ethylene glycol monomethyl ether. I. Subchronicvapor inhalation study with rats and rabbits. Fundamental and Applied Toxicology 3:49-54.

Mori K, Kaido M, Fujishiro K, Inoue N (1989) Testicular toxicity and alterations of glutathione metabolism resulting from chronic inhalation of ethylene oxide in rats, Toxicol Appl Pharmacol 101:299-309.

Nagano K, Nakayama E, Koyano M, Oobayashi H, Adachi H, Yamada T (1979) Testicular atrophy of mice induced by ethylene glycol mono alkyl ethers. Jpn $\mathrm{J}$ Ind Health 21:29-35

Nakajima Y, Tsuruma K, Shimazawa M, Mishima S, Hara H (2009)Comparison of bee products based on assays of antioxidant capacities. BMC Complementary and Alternative Medicine 9:1

Nitter-Hauge S (1970) Poisoning with ethylene glycol monomethyl ether. Report of two cases. Acta Med Scand 188:277-280.

Organisation Mondiale de la Santé (OMS) (2004) Critères de qualité d'air (air quality guidelines) et critères de qualité de l'eau potable (water sanitation).

Organisation mondiale de la santé (OMS) (1990) 2-methoxyethanol, 2ethoxyethanol, and their acetates, Programme international sur la sécurité des substances chimiques, Genève (Suisse), pp 126.

Parsons CE and Parsons MEM (1938) Toxic encephalopathy and 'granulopenicanemia' due to volatile solvents in industry: report of two cases. Journal of Industrial Hygiene and Toxicology, pp 120-124
Pastre JOC (2005) Intérêt de la supplementation en antioxydants dans l'alimentation des carnivores domestiques. Ecole Nationale Vétérinaire. Toulouse 3:4116.

Phillips KP and N Tanphaichitr (2008) Human exposure to endocrine disrupters and semen quality. Journal of Toxicology and Environmental Health 11:188-220.

Podsędek A (2007) Natural antioxidants and antioxidant capacity of brassica vegetables: A review. Food Science and Technology 40:1-11.

Pomierny B, Starek A, Krzyzanowska W, Starek-Swiechowicz B, Smaga I, Pomierny-Chamiolo L, Regulska M, Budziszewska B (2014) Potential neurotoxic effect of ethylene glycol ethers mixtures. Pharmacol Rep 65:1415-1421.

Prabhat K (2016) Biomagnetic Monitoring of Particulate Matter. $1^{\text {st }}$ Edition, Elsevier Science, pp216

Ranaivo HR , Rakotoarison O, Tesse A, Schott C, Randriantsoa A, Lobstein A, Andrian tsitohaina R (2004) Cedrelopsisgrevei induced hypotension and improved endothelial vasodilatation through an increase of $\mathrm{Cu} / \mathrm{Zn}$ SOD protein expression. Am J Physiol Heart Cric Physiol 286:775-781.

Rao VS and Shaha C (2002) N-acetylcysteine prevents MAA induced male germ cell apoptosis: role of glutathione and cytochrome c. FEBS. Toxicology Letters 527:133-137.

Ratcliffe JM et al 1989 Semen quality in workers exposed to 2-ethoxyethanol. British Journal of Industrial Medicine 46:399-406.

Reader SC, Shingles C, Stonard MD (1991) Acute testicular toxicity of 1,3dinitrobenzene and ethylene glycol monomethyl ether in the rat: evaluation of biochemical Adedara I A and Farombi E O 811 Downloaded from het.sagepub.com at NATIONAL CHUNG HSING UNIV on March 31, 2014 effect markers and hormonal responses. Fundam Appl Toxicol 16:61-70.

Riddle M, Williams W, Andrews D, Copeland C, Luebke R, Smialowicz R (1992) Species and strain comparisons of immunosuppression by 2-methoxyethanol (ME) and 2- methoxyacetic acid (MAA) Toxicologist 12:177.

Rooji DG (1998) Stem cells in the testis. Int J Exp Path 79: 67-80.

Sakurai $\mathrm{K}$ et al. 2015 MicroRNA profiling in ethylene glycol monomethyl ether-induced monkey testicular toxicity model. Journal of Toxicological Sciences 40:375-382.

Sax NI and Lewis RJ Sr (1989) Dangerous properties of industrial materials, 7th edition. Van Nostrand Reinhold, New York.

Scott WJ, Fradkin R, Wittfoht W, Nau H (1989) Teratologic potential of 2 methoxyethanol and transplacental distribution of its metabolite, 2methoxyacetic acid, in non-human primates.Teratology 39:363-373.

Shih TS, Hsieh AT, Liao GD, Chen YH, Liou SH (2000) Haematological and spermatotoxic effects of ethylene glycol monomethyl ether in copper clad laminate factories. Occup Environ Med 57:348-352.

Siriwardena AK (2014) Reappraisal of xenobiotic- induced, oxidative stressmediated cellular injury in chronic pancreatitis: A systematic review. World J Gastroenterol 20:3033-3043.

Sleet RB, Greene JA, Welsch F (1988) The relationship of embryotoxicity to disposition of 2-méthoxyéthanol in mice. Toxicol Appl Pharmacol 93:195207.

Smialowicz RJ, Riddle MM, Luebke RW, Copeland CB, Andrews D, Rogers RR, Gray, LE, Laskey JW (1991) Immunotoxicity of 2-methoxyethanol following oral administration in Fischer 344 rats.Toxicol Appl Pharmacol 109:494-506.

Starek A, Szymczak W, Zapor L (2008) Hematological effects of four ethylene glycol monoalkyl ethers in short-term repeated exposure in rats. Arch Toxicol 82:125-136.

Stemmler K, Mengon W, Kinnison DJ, Kerr JA (1997) OH radical-initiated oxidation of 2- butoxyethanol under laboratory conditions related to the troposphere: product studies and proposed mechanism. Environ Sci Technol 31:1496-1504.

Stanard B (2014) 2-Ethoxyethanol. Encyclopedia of Toxicology pp 503-505.

Stevens PF (2001) Angiosperm Phylogeny Website. Version 9. 
Suter L, Meier G, Bechter R, Bobadilla M (1998) Flow cytometry as a sensitive tool to assess testicular damage in rat. Archives of Toxicology 72:791-797.

Takagi A, Yamada T, Hayashi K, Nakade Y, Kojima T, Takamatsu J, Murate T (2002) Involvement Of Caspase 3 Mediated Apoptosis In Hematopoietic Cytotoxicity Of Metabolites Of Ethylene Glycol Monomethyl Ether. Industrial Health 40:371-374.

Tas S, Lauwerys R, Lison D (1996) Occupational hazards for the male reproductive system. Crit Rev Toxicol 26:261-307.

Timour Q, Biggi-Bernard U, Descotes J (2007) Hormonothérapie de substitution: toxicité des éthers de glycol. Journal de Gynécologie Obstétrique et Biologie de La Reproduction 36:62-67.

Tiwari A (1999) Natural product antioxidants and their therapeutic potential in mitigating peroxidative modification of lipoproteins and atherosclerosis: recent development. J Med Aroma Plant Sci 21:730-741.

Toyokuni S, Tanaka T, Kawaguchi W, Fang NR, Ozeki M, Akatsuka S, Hiai H, Aruoma OI, Bahorun T (2003) Effects of the phenolic contents of Mauritian endemic plant extract on promoter activities of antioxidant enzymes. Free Rad Res 37:1215-1224.

Udden MM (2000) Rat erythrocyte morphological changes after gavage dosing with 2-butoxyethanol: a comparison with thein vitro effects of butoxyacetic acid on rat and human erythrocytes. Journal of Applied Toxicology 20:381-387.

United States Environmental Protection Agency (US EPA) (1986) Health and environmental effects profile for 2-methoxyethanol, Environmental Criteria and Assessment Office, Cincinnati (Ohio) (EPA/600/x-87/025; NTIS PB89119531).

US Environmental Protection Agency (US EPA) (1986) Brominated diphenylethers. Chemical hazard information profile. Washington, DC, US Environ. Protection Agency.

Verschuere S, De Smet R, Allais L, Cuvelier CA (2012) The effect of smoking on intestinal inflammation: What can be learned from animal models. J Crohns Colitis 6:1-12

Veulemans $\mathrm{H}$ et al (1993) Exposure to ethylene glycol ethers and spermatogenic disorders in man: a case-control study. British Journal of Industrial Medicine 50:71-78.
Wang RS, Suda M, Gao X, Wang B, Nakajima T, Honma T (2004) Health effects of exposure to ethylene glycol monoethyl ether in female workers. Ind Health 42:447-451.

Watanable A, NakanoY, Endo T, Sato N, Kai K, Shiraiwa K (2000) Collaborative work to evaluate toxicity on male reproductive organs by repeated dose studies in rats. Repeated toxicity study on ethylene glycol monomethyl ether for 2 and 4 weeks to detect effects on male reproductive organs in rats. J Toxicol Sci, pp 259-266

Welch LS (1988) Effects of exposure to ethylene glycol ethers on shipyard painters: II. Male reproduction. American Journal of Industrial Medicine 14:509-526.

Welsch F (2005) Mechanism of ethylene glycol ether reproductive and developmental toxicity and evidence for adverse effects in humans. Toxicology Letters 156:13-28.

Welsch F, Sleet RB (1987) Metabolism and disposition of a teratogenic dose of 2-méthoxyéthanol (ME) in pregnant CD-1 mice. Teratology 36:16-22.

Wikström N, Savolainen V, Chase M (2001) Evolution of the angiosperms: Calibrating the family tree. Proc Roy Soc London B 268: 2211-2220.

Williams WC, Riddle MM, Copeland CB, Andrews DL, Smialowicz RJ (1995) Immunological effects of 2-methoxyethanol administered dermally or orally to Fischer 344 rats. Toxicology 98:215-223.

Yamamoto T, Horii I and Yoshida T (2007) Integrated nmr-based metabonomic investigation of early metabolic effects of ethylene glycol monomethyl ether (egme) on male reproductive organs in rats. The Journal of Toxicological Sciences 32:515-528.

Young EG, Woolner LB (1946) A case of fatal poisoning from 2-methoxyethanol. J Ind Hyg Toxicol 28:267-268.

Zastrow G, Gunther S, Postel W, Gorg A, Diehl H A and Jansen EH (1990) Serum proteins of rats exposed to organic solvents examined by horizontal two-dimensional electrophoresis with an immobilized $\mathrm{pH}$ gradient in the first dimension. Electrophoresis 11:655-657.

Zissu D (1995) Experimental study of cutaneous tolerance to glycol ethers. Contact Dermatitis 32:74-77. 